\title{
Effect of mefloquine on biological and biochemical aspects of Lymnaea natalensis snails infected with Fasciola gigantica
}

\author{
Marwa Thabet Atwa ${ }^{* *}$ and Fayez Ahmed Bakry²
}

\begin{abstract}
Background: The effect of the mefloquine drug on the survival rate, egg production, and infection of snails with Fasciola gigantica was studied. Also, the present study was designed to investigate the response of the snail Lymnaea natalensis for physiological and molecular aspects of the snail after exposure to mefloquine for 2 weeks.

Results: It was found that the exposure of Lymnaea natalensis snails to mefloquine drug led to a significant reduction in the survival rate and egg production. The results obtained also showed that infectivity of Lymnaea natalensis with Fasciola gigantica miracidia was greatly reduced by exposure to LC25 of mefloquine drug. The data showed that in treating snails, glucose concentration (GL) in the haemolymph as well as lactate (LT) in soft tissues of treated snails increased, while glycogen (GN), pyruvate (PV), total protein (TP), and nucleic acids (DNA and RNA) levels in snail's tissues decreased. In addition, the activity level of some enzymes representing glycolytic enzymes as hexokinase $(H K)$, pyruvate kinase (PK), phosphofructokinase (PFK), lactate dehydrogenase(LDH), and glucose phosphate isomerase (GPI) was also significantly reduced in response to treatment.
\end{abstract}

Conclusion: DNA changes were studied by comet assay and the overall results revealed that mefloquine drug has genotoxic effect.

Keywords: Mefloquine, Lymnaea natalensis, Fasciola gigantica

\section{Background}

Fascioliasis is a worldwide zoonotic disease caused by infection with either Fasciola hepatica or Fasciola gigantica (WHO, 2006). F. hepatica has worldwide in distribution but predominates in temperate zones while $F$. gigantica is found primarily in tropical regions (Agarwal \& Singh, 1988; Mas-Coma, Esteban, \& Bargues, 1999; Mas-Coma, Bargues, \& Valero, 2005). The definite host range is very broad and includes many herbivorous mammals including humans. Human fascioliasis has been reported from 51 countries from 5 continents (Mas-Coma et al., 2005). Fascioliasis is now recognized as one of the emerging human disease. World health organization has estimated that 2.4 million people are infected with Fasciola and a further 180 million are at risk of infection (WHO, 2006). Fascioliasis is cosmopolitan in distribution and is prevalent in sheep-

\footnotetext{
* Correspondence: mta00@fayoum.edu.eg

'Departement of Zoology, Faculty of Science, Fayoum University, Fayoum, Egypt

Full list of author information is available at the end of the article
}

raising countries. It is an increasingly important parasitic disease of man in the Mediterranean countries (El-Shazly, Hanjousa, Youssef, \& Hamouda, 1991). The parasite is transmitted to its final host through the molluscan intermediate host Lymnaea natalensis (Abdel-Latif, 1985; Allam, 1992; Hiekal, 1984). Now, it is an increasingly important parasite of man in the Mediterranean countries (El-Shazly et al., 1991; Lenton et al., 1996; Rangel-Ruiz, 1999). Several studies have been carried out on the prevalence of fascioliasis among humans, livestock, and the intermediate hosts and their role in the transmission of infection (Abdel-Latif, 1985; Allam, 1992; EL-Shabrawi, El-Karaksy, Okash, \& El-Hennacoy, 1997; Hiekal, 1984; Mas-Coma et al., 1999). One of the solutions to tackle with the problem of fascioliasis is to destroy the carrier snail and thus remove a link in their transmission cycle (Singh, Singh, Misra, \& Agarwal, 1996). It was reported that the parasites obtain their nutrients and many of their structural elements from the host for growth and energy generation (Thompson, Lee, Mejia-Scales, \& El-Din, 1993; 
Tielens, 1994). It is generally agreed that the most effective method for fascioliasis control is by the use of chemical molluscicides (Hariston, 1965; Shiff, 1961). Most of the researches have been carried on the use of synthetic molluscicides.

In the present study, attention has been focused on the effect of test drug on survival and egg laying of Lymnaea natalensis, infection rate of Lymnaea natalensis with Fasciola gigantica miracidia, biochemical parameters, and some enzymes. Further, effect of Mefloquine drug on molecular aspects of these snails was also studied.

\section{Methods}

\section{Fasciola gigantica ova}

Adult Fasciola gigantica (Looss, 1896) can be obtained from condemned livers of cattle and sheep. Cut across an infected liver and squeeze to recover flukes and eggs from the open ends of the biliary ducts. Adult worms were incubated at $37{ }^{\circ} \mathrm{C}$ for $2 \mathrm{~h}$ to collect large number of eggs escaping from adult worms. The remaining eggs in the worms were obtained by directing and examined worm under microscope. The eggs were put in the numbers of Petri-dishes containing dechlorinated tap water (DTW) at $26{ }^{\circ} \mathrm{C}$ for about 11 days.

\section{Snails}

Laboratory culture of Lymnaea natalensis was started by collecting a field strain from Giza Governorate in October, 2017. Placing each ten adult snails in a plastic aquarium containing $1 \mathrm{~L}$ of dechlorinated tap water. The snails were fed on blue-green algae and dried lettuce. Isolation of the egg masses was done by cutting the plastic sheet around each egg mass. Egg masses were kept in Petri dishes containing DTW and the developmental period was about 14 days at $20{ }^{\circ} \mathrm{C}$. A few days after hatching, the juvenile snails were transferred to another Petri dishes containing blue-green algae. During the first 1 or 2 weeks, about ten newly hatched snails could be kept in each Petri dish containing blue-green algae and reached infection size (3-5 mm shell height) 1 to 2 weeks after hatching.

\section{Drugs}

Mefloquine (Larium, $250 \mathrm{mg}$ tablets) was provided by F. Hoffmann-La Roche (Basel, Switzerland). The drug was suspended in 7\% Tween-80 and 3\% ethanol at a concentration of $40 \mathrm{~g} / \mathrm{L}$.

\section{Bioassay tests}

\section{Molluscicidal screening}

A stock solution of $500 \mathrm{ppm}$ mefloquine was prepared using dechlorinated tap water ( $\mathrm{pH} 7.0-7.5)$. A series of concentrations $(0.5,1,1.5,2,2.5,3$, and $4 \mathrm{ppm})$ that would permit the computation of LC50 and LC90 values were prepared (World Health Organization [WHO], 1965). Three replicates per each concentration and control were used (ten snails/each/L). Exposure period was $24 \mathrm{~h}$ each at $25+1{ }^{\circ} \mathrm{C}$. Sublethal concentrations were calculated from the lethal-dose probability lines designed according to the procedure of Litchfield and Wilcoxon (1949). The LC0 was estimated as $1 / 10$ LC50 (WHO, 1965).

\section{Effect of mefloquine on survival rate, egg production of Lymnaea natalensis}

For studying the survival and egg laying of Lymnaea natalensis specimens, 100 adult snails $(8-10)$ were randomly divided into 2 groups (50 snail each). One group was exposed continuously to LC25 of mefloquine till the death of all snails. The second group was left unexposed under the same laboratory conditions as a control. Mefloquine solutions were changed every $24 \mathrm{~h}$ with new prepared ones to avoid the effect of storage. Observations were made daily on the survivorship of the snails and the number of eggs laid. After each exposure period, snails were washed with dechlorinated tap water. The snails were daily fed boiled lettuce leaves. Each aquarium was provided with polyethylene sheets for oviposition. The egg masses and eggs laid on these sheets were counted using a binocular stereomicroscope. Dead snails are removed daily from aquaria and the mortality rate was calculated.

\section{The effect of mefloquine on infection rate of Lymnaea natalensis with Fasciola gigantica miracidia}

The effect of LC25 concentration of mefloquine on infection rate of Lymnaea natalensis with Fasciola gigantica miracidia was examined by exposing groups each of 50 snails individually to $F$. gigantica miracidia with a dose of 10 miracidia/snail and maintained in LC25 concentration of mefloquine for $24 \mathrm{~h}$ under room temperature $\left(24 \pm 1{ }^{\circ} \mathrm{C}\right)$ and ceiling illumination. After exposure to miracidia, snails were maintained in LC25 concentration of mefloquine. Another group of 50 snails was exposed to miracidia in the absence of the mefloquine solution and maintained under the same conditions (control group). After the 30th day postinfection, the snail were examined daily under a binocular dissecting microscope till the appearance of metaceracariae on the lettuce leaves or the cellophane paper or even on the shell of the snail.

\section{The physiological effects of $L C 25$ of the mefloquine drug}

Snails were randomly divided into 2 groups (50 snails each). The first group was continuously exposed for 2 weeks to LC25 of mefloquine. The second group of snails was left unexposed under the same laboratory conditions as a control. The snails surviving after exposure 
was used to study the effects of LC25 of mefloquine on physiological of these snails. For preparation of tissue extracts of snails exposed to mefloquine for 2 weeks as well as of the control snails, $1 \mathrm{~g}$ of the soft tissues of the snail was homogenized in $5 \mathrm{ml}$ distilled water of $\mathrm{pH} 7.5$. A glass homogenizer was then used to grind the tissue, and the homogenate was centrifuged for $10 \mathrm{~min}$ at $3000 \mathrm{rpm}$ and the fresh supernatant was decanted. Haemolymph of the treated and control snails was collected in accordance with the techniques described by Michelson (1966). The haemolymph was obtained via a small hole made in the shell in which capillary tube was inserted, then it was drawn into a tube by capillary suction. The haemolymph was pooled from ten snails collected in a vial tube $(1.5 \mathrm{ml})$ and kept in an ice-bath. All physiological parameters determined in this study were determined spectrophotometrically, using reagent kits purchased from Bio Merieux Company, France.

Assay methods Glucose concentration (GL) $(\mathrm{mg} / \mathrm{ml}$ haemolymph) in snails' haemolymph was measured according to Trinder (1969). Lactate (LT) was estimated according to Barker and Summerson (1941) as modified by Huckabee (1961). Lactate content was expressed as $\mathrm{mg}$ lactic acid/g of tissue. Total protein level (TP) was estimated according to the folin-phenol method of Lowry, Rosebrough, and Farr (1951); total protein content was expressed as $1 \mathrm{~g}$ protein $/ \mathrm{mg}$ of tissue. Glycogen (GN) was measured according to Van der Vies (1954).

Glycogen content was expressed as $\mathrm{mg}$ glycogen/g of tissue. The pyruvate level (PV) was measured according to Friedemann and Haugen (1943). The pyruvate content was expressed as $1 \mathrm{~mol}$ of pyruvate/g of tissue. Total nucleic acids (DNA and RNA) were estimated according to Schneider (1957), using diphenylamine and ordinal reagents, respectively. Nucleic acids content was expressed as $1 \mathrm{~g} / \mathrm{mg}$ of tissue.

Hexokinase (HK) was assayed according to the method of Uyeda and Racker (1965). Pyruvate kinase (PK) was assayed according to Mcmanus and James (1975). Phosphofructokinase (PFK) was measured according to the method of Zammit, Beis, and Newsholme (1978). Lactate dehydrogenase (LDH) activity was measured spectrophotometrically according to Cabaud and Wroblewskl (1958). Glucose phosphate isomerase (GPI) was measured using the method of King (1974).

\section{Effect of the mefloquine drug on molecular aspects of Biomphalaria alexandrina snails: comet assay (single-cell gel electrophoresis)}

This experiment was carried out to evaluate the genotoxic effect of LC25 of mefloquine in head foot of adult Lymnaea natalensis snails after exposed for $48 \mathrm{~h}$ to this drug at $25{ }^{\circ} \mathrm{C}$. The present work will study the genotoxic effect of the mefloquine drugs on snails. The adult snails (6-8 $\mathrm{mm}$ ) were exposed for $48 \mathrm{~h} /$ week (two successive days) to mefloquine A control group was maintained in dechlorinated tap water under the same laboratory conditions. Comet assay is used to evaluate the genotoxic potential of industrial chemicals, agrochemicals, biocides, and pharmaceuticals.

Comet assay is a micro gel electrophoresis technique that detects DNA damage and repair in individual cells. The damage is represented by an increase of the migration of DNA in an agarose matrix under electrophoresis condition which when viewed under microscope the nucleus has the appearance of the comet with the head (nuclear intact material) and a tail (containing damaged DNA fragment). The DNA fragments are generated by DNA double-strand breaks, single-strand breaks, and/or strand breaks induced by alkali labile sites and oxidative damage. The length and fragment content of the comet tail is directly proportional to the degree of DNA damage (according to Singh, McCoy, Tice, \& Schneider, 1988).

\section{Statistical analysis}

The data were statistically analyzed for the significance of differences between treated and control group by using " $t$ " test (Goldstein, 1964) and values were expressed as means \pm S.D. Values of biochemical parameters were statistically analyzed using " $t$ " test and analysis of variance (ANOVA) to determine the significant differences among groups of treated and the control group, using the statistical program for windows (GraphPad Prism 6.04 software; GraphPad Software, San Diego, CA, USA, 19922014). Statistically significant differences between groups were considered to have a $P$ value of $<0.05$.

\section{Image analysis}

The comet image was analyzed with Comet Assay IV software (free version) to obtain parameters such as comet length, tail length, tail moment, and DNA percentage in the tail.

\section{Results}

The molluscicidal activity of Mefloquine on Lymnaea natalensis snails after $24 \mathrm{~h}$ of exposure is presented in Table 1. The data obtained indicate that LC50 and LC90 values for Mefloquine were $11.2 \mathrm{ppm}$ and $22.4 \mathrm{ppm}$ respectively. The sublethal concentrations (LC0, LC10, and LC25) were found to be 1.12, 3.6, and $7.4 \mathrm{ppm}$ respectively.

The results presented in Table 2 indicate that the survival rate of snails, continuously exposed to LC25 of mefloquine, exhibited a sharp and quick drop as only $32 \%$ of snails survived after 5 weeks which is significantly lower than that of the control snails $(p<0.001)$. The snails exposed to LC25 of mefloquine showed a 
Table 1 Molluscicidal activity of Mefloquine on Lymnaea natalensis snails after $24 \mathrm{~h}$ of exposure under laboratory conditions

\begin{tabular}{lccccccc}
\hline Snail species & LC50 & Confidence limit of LC50 & Slope function & LC90 & LC0 & LC10 & LC25 \\
\hline Lymnaea natalensis & 11.2 & $9.3-13.5$ & 1.3 & 22.4 & 1.12 & 3.6 & 7.4 \\
\hline
\end{tabular}

decrease in their survival rate at 7 weeks of the experiment, reaching $12 \%$ which is significantly lower than that of the control group $(p<0.01)$.

It is clear from the results displayed in Table 2 that the groups of snails exposed to LC25 of mefloquine affected negatively the egg-laying capacity of the snails. Regarding the control snails, they began to lay eggs in the first week of the experiment, whereas in exposed group, snails began to lay eggs after 2 week. The total mean numbers of eggs laid by treated snails with LC25 mefloquine was $4.91 \mathrm{ppm}$, versus 32.12 in the control group. The percent reduction in the egg-laying capacity of the treated snails was $84.71 \%$, compared to that of the control.

The effect of LC25 of mefloquine on infection of Lymnaea natalensis with Fasciola gigantica miracidia was presented in Table 3. The infection rate was significantly lower than that of control snails (57.9\%), being $18.75 \%$ for snails exposed to mefloquine with a reduction rate 67.62 .

The present data showed that LC25 of the Mefloquine drug was enough to alter the biochemical parameters in soft tissues of the snail. Total protein glycogen, pyruvate, and nucleic acid (DNA and RNA) levels were reduced while the glucose concentration in the haemolymph and lactate level increased in tissues of Lymnaea natalensis

Table 2 Effect of Mefloquine drug on survival rate, egg production of Lymnaea natalensis

\begin{tabular}{|c|c|c|c|c|}
\hline \multirow[t]{2}{*}{ Weeks } & \multicolumn{2}{|l|}{ Mefloquine } & \multicolumn{2}{|l|}{ Control } \\
\hline & Survival \% & $\begin{array}{l}\text { Mean no. } \\
\text { of eggs/snail }\end{array}$ & Survival \% & $\begin{array}{l}\text { Mean no. } \\
\text { of eggs/snail }\end{array}$ \\
\hline 0 & 100 & - & 100 & - \\
\hline 1 & 78 & - & 98 & 1.8 \\
\hline 2 & 64 & 1.12 & 90 & 2.33 \\
\hline 3 & 56 & 1.2 & 78 & 5.2 \\
\hline 4 & 42 & 1.11 & 72 & 9.6 \\
\hline 5 & 32 & 0.86 & 65 & 4.6 \\
\hline 6 & 23 & 0.62 & 56 & 2.55 \\
\hline 7 & 12 & 0 & 48 & 2.4 \\
\hline 8 & 0 & 0 & 34 & 1.6 \\
\hline 9 & 0 & 0 & 28 & 1.2 \\
\hline 10 & 0 & 0 & 22 & 0.84 \\
\hline 11 & 0 & 0 & 15 & 0 \\
\hline Ro & & 4.91 & & 32.12 \\
\hline \%change & & $84.71 \%$ & & \\
\hline
\end{tabular}

after exposure to the dug for 2 weeks. GL and LT concentration was increased to $-21.1 \%$ and $-40.13 \%$ in haemolymph and tissue, respectively. TP, GN content, PV, DNA, and RNA were reduced to $31.54 \%,-46.7 \%$, $18.75 \%, 25 \%$, and $43 \%$, respectively (Table 4 and Fig. 1 ).

The levels of glycolytic pathway as hexokinase (HK), pyruvate kinase (PK), phosphofructokinase (PFK), lactate dehydrogenase (LDH), and glucose phosphate isomerase (GPI) in the soft tissue in normal and treated snails are displayed in Table 5. The HK activity in snails exposed to LC25 of the Mefloquine drug for 2 weeks was $3.6 \pm$ $0.44 \mathrm{mmol} / \mathrm{min} / \mathrm{g}$ wet $33 \%$. Such reduced values were statistically significant than those of the corresponding controls $(5.4 \pm 0.22 \mathrm{mmol} / \mathrm{min} / \mathrm{g})$. The activity levels of PK, PFK, LDH, and GPI were also significantly reduced in response to treatment with the Mefloquine drug, the percentage of reduction was $33 \%, 58.8 \%, 28.38 \%$, and $56.25 \%$ (Table 5).

It is shown from Table 6 and Fig. 1 that under alkaline conditions, comet assay directly correlates single-strand breaks (SSBs) with the olive tail moment, which is defined as the product of the distance between the head and the center of gravity of DNA in the tail and the percentage of DNA in the comet tail (Kumaravel \& Jha, 2006). The present results of alkaline comet assay demonstrated that the level of SSBs induced by this drug was significantly higher than that in control group. The present results (Table 6 and Fig. 2) declared that the olive tail moment (OTM) of snails exposed for $48 \mathrm{~h}$ to LC25 of Mefloquine was increased and that there are a very highly significant differences between the value of treated and control snails $(p=0.001)$ being $4.4 \pm 0.35$, compared to $2.31 \pm 0.120 \mu \mathrm{m}$ for control.

For ranking each comet, we followed the original method developed by Collins (2002). The common method for scoring the comet, other than by computers, is by measuring tail length, head size, tail intensity, and head intensity (Collins, 2002; Olive, 2002). Comets were classified and assigned to two categories $(0,2)$ according to the extent of DNA migration, i.e., tail length (Grazeffe et al., 2008), and this classification was carried out in the following way: comets with bright heads and no apparent tails were assigned to category 0 , comets with very little heads and long, diffused tails to category 2. Comets displaying features intermediary between categories 0 and 2 were divided and assigned to easily distinguishable categories (Figs. 1 and 2). It is noticed that for rank 0, control group; whereas for rank 2, adult snail that subjected to Mefloquine take this rank. 
Table 3 Effect of Mefloquine drug on infectivity of Fasciola gigantica miracidia for Lymnaea natalensis snails

\begin{tabular}{|c|c|c|c|c|c|c|}
\hline \multirow[t]{2}{*}{ Treatment } & \multirow{2}{*}{$\begin{array}{l}\text { Number of } \\
\text { exposed snails }\end{array}$} & \multicolumn{2}{|c|}{ Survived snails at first shedding } & \multicolumn{2}{|c|}{ Infected snails } & \multirow[t]{2}{*}{$\%$ Reduction } \\
\hline & & Number & $\%$ & Number & $\%$ & \\
\hline Control & 50 & 36 & 72 & 22 & 57.9 & \\
\hline Mefloquine drug & 50 & 16 & 32 & 3 & 18.75 & 67.62 \\
\hline
\end{tabular}

\section{Discussion}

The present results cleared that mefloquine has a toxic effect against Lymnaea natalensis snails expressed by LC50 and LC90 values of $11.2 \mathrm{ppm}$ and $22.4 \mathrm{ppm}$, respectively after 24-h exposure according to WHO (1965). These findings are supported by those of Marston et al. (1993) and Hafez et al. (2007) who reported that Artemisia spp. had a molluscicidal activity against Biomphalaria snails.

The results of the present investigation have indicated a significant decrease in the survival rates of snails exposed to LC25 mefloquine. This finding agrees with the reduction in the survival rate of snails exposed to plant molluscicides recorded by Abdel hamid and El-Metwally (2008), Bakry and Said (2006), Bakry and Sharaf El-Din (2000), Gawish (2008), Hasheesh, Mohamed, and El-Monem (2011), Mostafa and Sharaf El-Din (2003), Moustafa et al. (2006), and Sharaf El-Din and El-Sayed (2001). Similar observations were noticed by Sharaf El-Din, El-Sayed, and Mahmoud (2004) using the herbicide dithiopyridine carboxylic acid, Mahmoud (2006) using the insecticides regent and mimic, Abdel Raouf (2007) using the insecticide, and Esmaeil (2009) using the fungicide. They found that there was also a marked reduction in the survival rate of snails treated with sublethal concentrations of molluscicides.

The egg production of snails treated with LC25 of Mefloquine has also shown a significant reduction. This may be due to the active substance present in the drugs

Table 4 The effect of prolonged exposure to LC25 of Mefloquine drug for 2 weeks on different biochemical parameters in the haemolymph and tissues of Lymnaea natalensis

\begin{tabular}{lcll}
\hline & $\begin{array}{c}\text { Control } \\
\text { Mean } \pm \text { SD }\end{array}$ & $\begin{array}{l}\text { Mefloquine drug } \\
\text { Mean } \pm \text { SD }\end{array}$ & \% change \\
\hline Glucose haemolymph (GL) & $38.2 \pm 1.2$ & $46.6 \pm 1.4^{*}$ & $-21.1 \%$ \\
Lactate (LT) & $1.57 \pm 0.33$ & $2.2 \pm 0.38^{* *}$ & $-40.13 \%$ \\
Total protein (TP) & $58.6 \pm 2.4$ & $40.12 \pm 3.4^{*}$ & $31.54 \%$ \\
Glycogen content (GN) & $4.5 \pm 0.82$ & $2.4 \pm 0.4^{*}$ & $46.7 \% *^{*}$ \\
The pyruvate content (PV) & $3.2 \pm 0.8$ & $2.6 \pm 0.45^{*}$ & $18.75 \%$ \\
DNA & $35.6 \pm 3.4$ & $26.4 \pm 3.4^{*}$ & $25 \%$ \\
RNA & $18.6 \pm 3.4$ & $10.6 \pm 0.84^{*}$ & $43 \%$ \\
\hline
\end{tabular}

$p^{*}<0.05 ; p^{* *}<0.01$ which could affect the internal mechanism inside the snails to lay eggs.

This result is supported by Bakry (2009), Bakry, Abd el salam, Mahmoud, and Hamdi (2012), Bakry, El-Hommossany, and Ismil (2016), Bakry, Tantawy, Ragab, and Abdel Kader (2001), and Tantawy (2002). The reduction of egg production in treated snails could be attributed to their high mortality rates, different periods of ceasing oviposition during the experimental period, and deteriorations in the activities of antioxidant enzymes SOD, CAT, GR, peroxidation, TrxR, SDH, and fatty acid profile and protein patterns, which means a damage to the snails' cells, interrupting their physiological activities, suppressing their oviposition $(\mathrm{Mx})$, and the reproductive rate (Ro) (El-Ansary, Sammour, Soliman, \& Gawish, 2001; Ibrahim, 2006; Youssef, 2010).

In this study, the infectivity of Fasciola gigantica miracidia for Lymnaea natalensis was greatly reduced by the tested drug. These results accord mostly with many authors working on various chemical and plant molluscicides. These results are supported by that of El-Sayed, Mohamed, and Mossalem (2011) who found that exposure of B. alexandrina and Biomphalaria glabrata snails to sublethal concentration of latex 3 days pre-miracidial exposure led to a significant reduction in the infection rate with Schistosoma mansoni of $55.47 \%$ and $58.9 \%$, respectively. Also, Mahmoud (2011) recorded a reduction

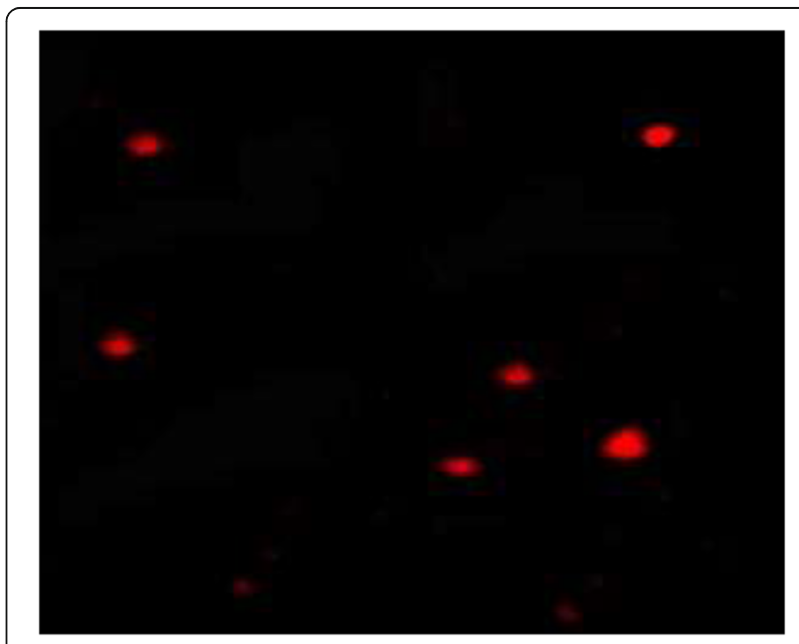

Fig. 1 Representative images of alkaline comet assay for control (rank 0) 
Table 5 Effect of prolonged exposure to LC25 of Mefloquine drug for 2 weeks on some glycolytic enzymes in soft tissues of Lymnaea natalensis snails

\begin{tabular}{llll}
\hline Parameters treatment & Control & Mefloquine drug & Mean \pm SD \\
\hline Hexokinase (HK) & $5.4 \pm 0.22$ & $3.6 \pm 0.44^{* * *}$ & $33 \%$ \\
Pyruvate kinase(PK) & $1.8 \pm 1.4$ & $1.2 \pm 0.8^{* * *}$ & $33 \%$ \\
phosphofructokinase (PFK) & $3.4 \pm 2.8$ & $1.4 \pm 1.5^{* * *}$ & $58.8 \%$ \\
Lactate dehydrogenase(LHD) & $7.4 \pm 2.4$ & $5.3 \pm 1.4^{* *}$ & $28.38 \%$ \\
Glucose phosphate isomerase (GPI) & $2.56 \pm 0.56$ & $1.12 \pm 0.33^{* * *}$ & -56.25 \\
\hline
\end{tabular}

${ }^{*} p<0.05 ;{ }^{* *} p<0.01 ;{ }^{* * *} p<0.001$. Enzyme activity $\mu \mathrm{mol} / \mathrm{min} / \mathrm{mg}$ protein

in infection rate of $B$. alexandrina snails exposed to profenophos pesticide compared to control group. This may be explained by the deterioration of physiological parameters of snails making them unsuitable for the parasite development (Gawish, 2008). These results accord mostly with many authors working on various chemical and plant molluscicides (Bakry \& Abdel-Monem, 2005; Bakry, Said, \& Ismail, 2007; Hasheesh et al., 2011; Tantawy, Sharaf El-Din, \& Bakry, 2000).

The present result showed that the reduction in glycogen content in the body tissues of Lymnaea natalensis snails and glucose increased in haemolymph indicates its rapid utilization by the respective tissues as a consequence of drug toxic stress. Under hypoxic conditions, animals derive their energy from anaerobic breakdown of glucose, which is available to the cells by increased glycogenolysis (Vincent, Ambrose, Cyrill, \& Selvanaygam, 1995). Nakano and Tomlinson (1967) have suggested that catecholamine levels rise under stressful environmental conditions, enabling the increased utilization of glycogen for energy production. Glycogen levels appear to be related, at least to some extent, to the detoxification mechanisms, essential for metabolism or degradation and elimination of herbicides from the body (Sambasiva, 1999).

The decrease in pyruvate levels is due to the higher energy demand during drug exposure, and suggests the possibility of a shift toward anaerobic dependence due to a notable drop in the aerobic segment. The decrease in pyruvate could be due to its conversion to lactate, or its mobilization to form amino acids, lipids, triglycerides, and glycogen synthesis in addition to its role in detoxification (Sathya, 1983). The depletion of the protein fraction in the body tissues of the snails in this experiment

Table 6 Effect LC25 of Mefloquine of on olive tail moment (OTM) and tail length of DNA of Lymnaea natalensis snails (mean \pm SD)

\begin{tabular}{llll}
\hline Groups & $\begin{array}{l}\text { Olive tail moment } \\
(\mathrm{OTM})(\mu \mathrm{m})\end{array}$ & Tail length $(\mathrm{Px})$ & $\begin{array}{l}\text { Rank of } \\
\text { DNA damage }\end{array}$ \\
\hline Control & $2.31 \pm 0.120$ & $7.3 \pm 0.5$ & 0 \\
Mefloquine & $4.4 \pm 0.35^{*}$ & $14.6 \pm 0.5$ & 2 \\
\hline${ }^{*} p<0.05$ & & &
\end{tabular}

may have been due to protein degradation for metabolic purposes. Under stress conditions, the dietary protein consumed by snails is not stored in the body tissue (Baskaran \& Palanichamy, 1990) and hence the treated snails met their extra energy requirements of body proteins which are mobilized to produce glucose, the instant energy of which is made available for the snail by the process of gluconeogenesis (Vasanthi, Baskaran, \& Palanichamy, 1990). Thus, the decreased protein content may be attributed to the destruction/necrosis of cells and consequent impairment in protein synthesis machinery (Bradbury, Makim, \& Coats, 1987). The increase in lactate also suggests a shift toward anaerobiosis as a consequence of hypoxia created from pesticide toxic impact leading to respiratory distress (Domsche, Domsche, \& Classen, 1971).

Drug appears as a potential inhibitor of DNA synthesis, which might also result in a reduction of the RNA level. It might also be noted that deprivation of food possibly caused some nutritional deficiency in the test snails, leading to lower concentration of nucleic acids and aberrations in DNA-directed RNA formation and

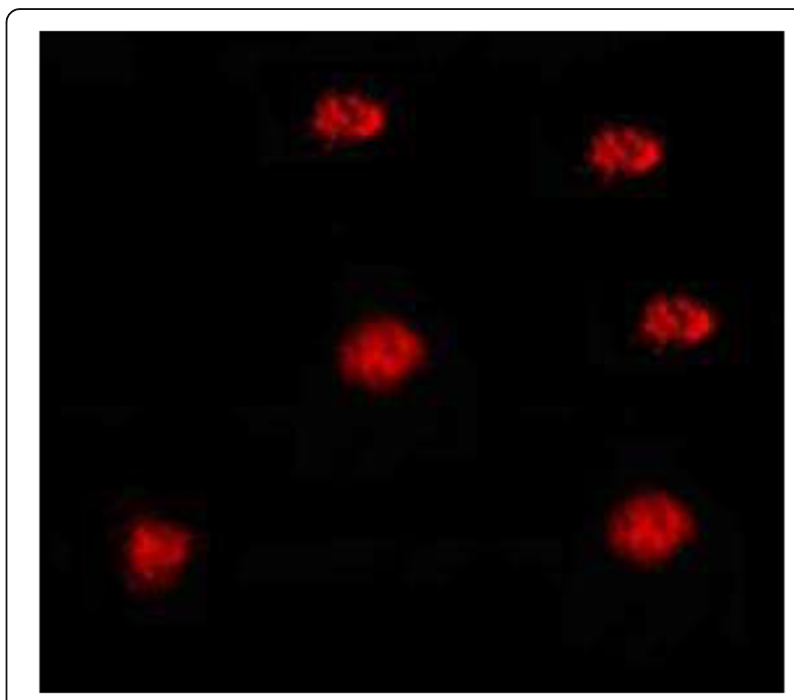

Fig. 2 Representative images of alkaline comet assay for treated snails with LC25 of Mefloquine (rank 2) 
protein synthesis, consequently limiting growth and adding to the metabolic stress of the snails (Eastman \& Barry, 1992).

In the present report, the glycolytic enzymes hexokinase (HK), pyruvate kinase (PK), phosphofructokinase (PFK), and lactate dehydrogenase (LDH) in the snail tissues showed variable decrease between significant and highly significant on applying the tested drug. The depletion in HK activity in the soft tissues causes an alteration of glycolytic mechanism which in turn induces a state of anoxia. A similar effect was detected by Bakry, Ismail and EL-Monem (2004), Bakry, Ragab and Sakran (2002), and Botros, Mahmoud, Moussa and Nosseir (2007) using plant extracts.

The present study showed a significant decrease in LDH activity in the whole tissue extract of Lymnaea natalensis in response to treatment with LC25 of the tested drug. Several authors have reported significant decline in LDH activity of tissues of various mollusks in response to some molluscicides (Aboul-zahab \& Al-ansary, 1992; Singh \& Agarwal, 1991). The decreased in LDH activity of Lymnaea natalensis's tissue was due to the release of the enzyme from the tissues as a result of cellular damage caused by the toxic effect of molluscicides. Some authors reported that tissue damage followed the release of cellular enzymes such as LDH (Paul, Bekker, \& Duran, 1990; Prasad et al., 1991). In spite of the decrease in LDH activity, there was insignificant change in D-lactate and pyruvate level as compared to untreated snails, as reported by Reddy, Venugopal, and Reddy (1995).

The results of alkaline comet assay of the present study demonstrated that the level of SSBs induced by the test drug at the tested concentration (LC25) was significantly higher in treated snails than that in control group and that this genotoxic effect was found in adult. This agrees with Ye et al. (2012), who stated that the relative amount of DNA strand breaks were higher after exposure to standard well known DNA damaging chemicals such as herbicides compared with controls.

These genotoxic effects agree with Hassab El-Nabi, Mohamed, and Osman (2001) who recorded that exposure of $B$. alexandrina snails to gibbrellic acid (plant growth hormone) at a low concentration $(10 \mathrm{ppm})$ induced more expression in snails' ovotestis tissues, while at a high concentration $(40 \mathrm{ppm})$ low RNA expression was observed in comparison with control group, and by exposure to Starane (herbicide) amount of RNA increased at all applied dose. These results could be discussed according to positive and negative gene regulatory mechanism (Palmiter, 1994). Mohamed, Osman, Mohamed, Hassab El-Nabi, and Sheri (2004) stated that exposure of Bellamya unicolor snails to cadmium chloride increased the intensity of RNA in their digestive and ovotestis glands after $24 \mathrm{~h}$ of exposure and decreased it post 5 days, which could be due to an activation of the transcription of some genes in the case of increase RNA intensity and block others in the intensity decrement. Similar conclusion was recorded by Esmaeil (2009) on the increase of RNA intensity in the ovotestis-digestive gland complex of $B$. alexandrina snails treated with the fungicide Topas during short exposure periods $(6,24$, and $72 \mathrm{~h})$ and decreasing it after long-term exposure (4 weeks). However, Colchicine was recorded to inhibit RNA transport rather than RNA processing in rats' liver cells which may be due to its specific binding with nuclear membrane (Schumm \& Webb, 1982).

Mohamed, El-Emam, Osman, Abdel-Hamid, and Ali (2012) stated that the damage of DNA (apoptosis, doublestrand breaks) in ovotestis-digestive gland complex of $B$. alexandrina snails was detected after 4 weeks of exposure to Basudin, Selecron, Bayluscide, and Colchicine.

\section{Conclusion}

The present results cleared that mefloquine has a toxic effect against Lymnaea natalensis snails expressed by LC50 and LC90 values of $11.2 \mathrm{ppm}$ and $22.4 \mathrm{ppm}$, respectively after 24-h exposure. The results of the present investigation have indicated a significant decrease in the survival rates of snails exposed to LC25 mefloquine. The egg production of snails treated with LC25 of Mefloquine has also shown a significant reduction. The infectivity of Fasciola gigantica miracidia for Lymnaea natalensis was greatly reduced by the tested drug. The present result showed that the reduction in glycogen content in the body tissues of Lymnaea natalensis snails and glucose increased in haemolymph indicates its rapid utilization by the respective tissues as a consequence of drug toxic stress. Drug appears as a potential inhibitor of DNA synthesis, which might also result in a reduction of the RNA level. Glycolytic enzymes hexokinase (HK), pyruvate kinase (PK), phosphofructokinase (PFK), and lactate dehydrogenase (LDH) in the snail tissues showed variable decrease between significant and highly significant on applying the tested drug. The present study showed a significant decrease in LDH activity in the whole tissue extract of Lymnaea natalensis in response to treatment with LC25 of the tested drug. The results of alkaline comet assay of the present study demonstrated that the level of SSBs induced by the test drug at the tested concentration (LC25) was significantly higher in treated snails than that in control group and that this genotoxic effect was found in adult. 


\section{Abbreviations}

GL: Glucose concentration; GN: Glycogen; GPI: Glucose phosphate isomerase; HK: Hexokinase; LDH: Lactate dehydrogenase; LT: Lactate; PFK: Phosphofructokinase; PK: Pyruvate kinase; PV: Pyruvate; TP: Total protein

\section{Acknowledgments}

Great thanks to Medical Malacology Theodor Bilharz Research Institute for providing the laboratory facility.

\section{Funding}

Not applicable.

\section{Availability of data and materials}

All database are available upon request.

\section{Authors' contributions}

MTA and FAB were responsible for suggesting, planning, and designing the study. The supervision of the laboratory work was performed by FAB. All authors cooperate in writing the manuscript and have read and approved the final manuscript

\section{Ethics approval and consent to participate}

Not applicable.

\section{Consent for publication}

Not applicable.

\section{Competing interests}

The authors declare that they have no competing interests.

\section{Publisher's Note}

Springer Nature remains neutral with regard to jurisdictional claims in published maps and institutional affiliations.

\section{Author details}

'Departement of Zoology, Faculty of Science, Fayoum University, Fayoum, Egypt. ${ }^{2}$ Departement of Medical Malacology, Theodor Bilharz Research Institute, Giza, Egypt.

Received: 3 August 2018 Accepted: 29 November 2018 Published online: 09 January 2019

\section{References}

Abdel hamid, M. T., \& El-Metwally, I. M. (2008). Growth, nodulation, and yield of soybean and associated weeds as affected by weed management. Planta Daninha, 26(4), 855-863.

Abdel Raouf, H. A. (2007). Comparative studies of the effect of certain synthetic compounds and a plant molluscicide on the fresh water snail, Biomphalaria alexandrina and some of its larval parasites. Egypt: M.Sc. Thesis, Zoology Department, Faculty of Science, Al-Azhar University.

Abdel-Latif, A. S. M. (1985). Epidemiological and biological studies on fascioliasis in Abis 1 village, Behera Province. Ph.D. Thesis, High Institute of Public Health, Alexandria University

Aboul-zahab, A. O., \& Al-ansary, A. (1992). Biological aspects of controlling snail hosts of bilharziasis using wild and cultivated plant extracts. Annals of Agricultural Science, Moshtohor (Egypt), 30, 1531-1539.

Agarwal, R. A., \& Singh, D. K. (1988). Harmful gastropods and their control. Acta Hydrochimica et Hydrobiologica, 16, 113-138.

Allam, A. F. M. (1992). Studies on the Lymnaea fasciola (host-parasite) relationship in Abis area. Ph.D. Thesis, High Institute of Public Health, Alexandria University.

Bakry, F. A. (2009). Impact of some plant extracts on histological structure and protein patterns of Biomphalaria alexandrina snails. Global Journal of Molecular Sciences, 4(1), 34-41.

Bakry, F. A., Abd el salam, H. A., Mahmoud, M. B., \& Hamdi, S. A. H. (2012). Influence of atrazine and roundup pesticides on biochemical and molecular aspects of Biomphalaria alexandrina snails. Pesticide Biochemistry and Physiology, 104, 9-18.

Bakry, F. A., \& Abd El-Monem, S. (2005). Effect of water plants and non- target snails onthe infectivity of Bulinus truncatus with Schistosoma haematobium Journal of the Egyptian Society of Parasitology, 35(3), 859-874.
Bakry, F. A., El-Hommossany, K., \& Ismil, S. M. (2016). Alterations in the fatty acid profile, antioxidant enzymes and protein pattern of Biomphalaria alexandrina snails exposed to the pesticides Basudin and Selecron. Toxicology and Industrial Health, 32(4), 666-676.

Bakry, F. A., Ismail, S. M., \& EL-Monem, S. (2004). Effect of two plant extracts on some biological and enzymatic activities of Bulinus truncatus with Schistosoma haematobium. Journal of Aquatic Biology and Fisheries, 8, 313-446.

Bakry, F. A., Ragab, F. M. A., \& Sakran, A. M. A. (2002). Effect of some plant extracts with molluscicidal properties on some biological and physiological parameters of Biomphalaria alexandrina snails. Journal-Egyptian German Society of Zoology, 38, 101-111.

Bakry, F. A., \& Said, A. A. (2006). Effect of some environmental factors on the molluscicidal activity of ethanol plant extracts against Biomphalaria alexandrina. Journal-Egyptian German Society of Zoology, 50(A), 181-206.

Bakry, F. A., Said, A. A., \& Ismail, S. M. (2007). Molluscicidal effect of and niclosimide on some biological and physiological parameters of lymnaea natalensis snails as intermediate host of fasciola gigantica. Egyptian Journal of Zoology, 46, 227-244.

Bakry, F. A. \& Sharaf El-Din, A. T. (2000). Effect of sub-lethal concentrations of Baylucide on Biomphalaria alexandrina. Journal-Egyptian German Society of Zoology, 31(D), 15-25.

Bakry, F. A., Tantawy, A. A., Ragab, F. M. A., \& Abdel Kader, A. (2001). Effect of sublethal concentrations of Agave franzosini plant (Agavaceae) on the infectivity of Schistosoma mansoni to Biomphalaria alexandrina snails. Journal-Egyptian German Society of Zoology, 35(D), 129-141.

Barker, S. B., \& Summerson, W. H. (1941). The colorimetric determination of lactic acid in biological materials. The Journal of Biological Chemistry, 138, 535-542.

Baskaran, P., \& Palanichamy, S. (1990). Impact of agricultural (ammonium chloride) fertilizer on physiology and biochemistry of fresh water teleost fish, Oreochromis mossambicus. Journal of Ecobiology, 2, 97-106.

Botros, S. S., Mahmoud, M. R., Moussa, M. M., \& Nosseir, M. M. (2007). Immunohistopathological and biochemical changes in Schistosoma mansoniinfected mice treated with artemether. The Journal of Infection, 55, 47-477.

Bradbury, S. P., Makim, J. R., \& Coats, J. R. (1987). Physiological responses of rainbow trout, Salmo gairdneri to acute fenvalerate intoxication. Pesticide Biochemistry and Physiology, 27, 275-285.

Cabaud, P., \& Wroblewskl, F. (1958). Colorimetric measurement of lactic dehydrogenase activity of body fluids. American Journal of Clinical Pathology, 30, 234.

Collins, A. R. (2002). Comet assay-principles, applications, and limitations. Methods in Molecular Biology, 203, 163-177.

Domsche, S., Domsche, W., \& Classen, M. (1971). Zum mechanisms deri Leber Zeuschadigung durch Alkaylphosphate. Natururissenchaflan, 58, 575-578.

Eastman, A., \& Barry, M. A. (1992). The origins of DNA breaks: a consequence of DNA damage, DNA repair, or apoptosis. Cancer Investigation, 10(3), 229-240.

El-Ansary, A., Sammour, E. M., Soliman, M. S., \& Gawish, F. A. (2001). In vivo, attenuation of schistosome cercarial development and disturbance of egg laying capacity in Biomphalaria alexandrina using sublethal concentrations of plant molluscicides. Journal of the Egyptian Society of Parasitology, 31, 657-669.

El-Sayed, K. A., Mohamed, M. B., \& Mossalem, H. S. (2011). Cryptostegia Grandiffora affecting compatibility of Biomphalaria Alexandrina and Biomphalaria Galabrata to infection with Schistosoma mansoni with emphasis on some hematological effects. Australian Journal of Basic and Applied Sciences, 5(12), 2210-2217.

EL-Shabrawi, M., El-Karaksy, H., Okash, S., \& El-Hennacoy, A. (1997). Human fascioliasis: clinical features and diagnostic difficulties in Egyptian children. Journal of Tropical Pediatrics, 43, 162-166.

El-Shazly, A. E., Hanjousa, A. E., Youssef, M. E. H., \& Hamouda, M. M. (1991). Human fascioliasis. A parasitic health problem in Dakahlia governorate, Egypt. Journal of the Egyptian Society of Parasitology, 21, 553-559.

Esmaeil, E. A. (2009). Biological and irnmunological studies on Biomphalaria alexandrina snails, the intermediate host of Schistosoma mansoni in Egypt. Egypt: Ph.D. Thesis, Faculty of Science, Menufia University.

Friedemann, T. E., \& Haugen, G. F. (1943). Pyruvic acid. I. Collection of blood for the determination of pyruvic acid and lactic acid. The Journal of Biological Chemistry, 144, 67-77.

Gawish, F. A. (2008). Activity of the plant Syzygium jambos against Biomphalaria alexandrina snails' reproduction and infection with Schistosoma mansoni. New Egyptian Journal of Medicine, 39(6), 103-110.

Goldstein, A. (1964). Biostatistics: An introductory text, (p. 51). New York: Macmillan.

Grazeffe, V. S., Tallarico, L. F., de Sa Pinheiro, A., Kawano, T., Suzuki, M. F., Okazaki, K. ... Nakano, E. (2008). Establishment of the comet assay in the freshwater snail Biomphalaria glabrata (Say, 1818). Mutation Research, 654, 58-63. 
Hafez, S. M., Hussein, M. I., Hassan, S. I., El-Shennawy, A. M., El-Komy, W. M., \& Amer, N. M. (2007). Evaluation of molluscicidal and schistosomicidal activity of two species of Egyptian Artemisia plant in schistosomiasis mansoni. New Egyptian Journal of Medicine, 36(5), 256-264.

Hasheesh, W. S., Mohamed, R. T., \& El-Monem, S. A. (2011). Biological and physiological parameters of Bulinus truncatus snails exposed to methanol extract of the plant Sesbania sesban plant. Advances in Biological Chemistry, 1, 65-73.

Hassab El-Nabi, S. E., Mohamed, A. H., \& Osman, G. Y. (2001). Estimation of RNA electrophoretic pattern as an indicator of pollution in Biomphalaria alexandrina snails treated with certain plant growth regulators, an herbicide and lead acetate. Journal of Union of Arab Biologists, 15(A), 467-486.

Hiekal, F. A. A. (1984). Certain studies on Fasciola spp in Behera governorate with special reference to the molluscicids of some plants and chemicals on snail intermediate host. Ph.D. Thesis, Faculty of Veterinary Medicine, Alexandria University.

Huckabee, W. E. (1961). Blood analysis, determination of lactic acid. In B. L. Oser (Ed.), Hawk's physiological chemistry, (p. 1103). New Delhi: Tata McGraw-Hill.

Ibrahim, M. M. (2006). Energy allocation patterns in Biomphalaria alexandrina snails in response to cadmium exposure and Schistosoma mansoni infection. Experimental Parasitology, 122, 31-36.

King, Y. S. (1974). Cultivation of Bulinus physopsis globosous (Morelt) and Biomphalaria pfeifferi (Krauss) snail hosts of schistosomiasis. Sterkiana, 7, 52-54.

Litchfield, J. T., \& Wilcoxon, F. (1949). A simplified method of evaluating dose effect experiments. The Journal of Pharmacology and Experimental Therapeutics, 96, 99-113.

Lowry, O. H., Rosebrough, N. J., \& Farr, R. J. (1951). Randall, protein measurement with Folin phenol reagent. The Journal of Biological Chemistry, 193, 265-275.

Mahmoud, M. B. (2006). Biological and histological impacts of the insecticides regent and mimic on Biomphalaria alexandrina snails. Egyptian Journal of Zoology, 46, 11-21.

Mas-Coma, M. S., Esteban, J. G., \& Bargues, M. D. (1999). Epidemiology of human fascioliasis: a review and proposed new classification. Bulletin of the World Health Organization, 77(4), 340-346.

Mas-Coma, S., Bargues, M. D., \& Valero, M. A. (2005). Fascioliasis and other plant-borne trematode zoonoses. International Journal for Parasitology, 35(11-12), 1255-1278.

Mcmanus, D. P., \& James, B. L. (1975). Anaerobic glucose metabolism in the digestive gland of Littorina saxatilis rudis (Maton) and the daughter sporocysts Microphallus similis (jag). Comparative Biochemistry and Physiology, 51, 293-297.

Michelson, E. H. (1966). Specificity of hemolymph antigens in taxonomic discrimination of medically important snails. The Journal of Parasitology, 52, 466-472.

Mohamed, A. M., El-Emam, M. A., Osman, G. Y., Abdel-Hamid, H., \& Ali, R. E. M. (2012). Effect of Basudin, Selecron and the phytoalkaloid colchicine (pesticides) on biological and molecular parameters of Biomphalaria alexandrina snails. Pesticide Biochemistry and Physiology, 102, 68-78.

Mohamed, A. M., Osman, G. Y., Mohamed, A. H., Hassab El-Nabi, S. E., \& Sheri, K. (2004). Histological and molecular studies of freshwater bivalves caelatura sp. treated with earthtec as a biomonitor to pollution. Proceedings / C B S, 3(1), 157-184.

Mostafa, B. B., \& Sharaf El-Din, A. T. (2003). Effect of the plants Thymus cabitatus and Piper nigrum on susceptibility of Biomphalaria snails and albino mice to schistosoma mansoni. Egyptian Journal Applied Science, 18(12), 15-23.

Moustafa, G. G., Ibrahim, Z. S., Hashimoto, Y., Alkelch, A. M., Sakamoto, K. Q. Ishizuka, M., \& Fujita, S. (2006). Testicular toxicity of profenofos in matured male rats. Archives of Toxicology, 81(12), 875-881.

Nakano, T., \& Tomlinson, N. (1967). Catecholamine and carbohydrate concentrations in rainbow trout (Salmo gairdneri) in relation to physical disturbance. Journal of the Fisheries Research Board of Canada, 24, 1707-1715.

Palmiter, R. D. (1994). Regulation of metalothionein genes appears to be mediated by zing-sensitive inhibitors that interacts with a constitutively active MTF-1. Proceedings of the National Academy of Sciences of the United States of America, 91, 1219-1223.

Paul, J., Bekker, A. Y., \& Duran, W. N. (1990). Calcium entry prevents leakage of macromolecules induced by ischemia-reperfusion in skeletal muscle. Circulation Research, 66, 1636-1642.

Prasad, M. R., Popeseu, L. M., Moraru, I. I., Liu, X., Maity, S., Engelmanr, M., \& Das, D. (1991). Role of phospholipase $A$ and $C$ in myocardial ischemic reperfusion injury. The American Journal of Physiology, 29, 877-883.
Reddy, A. N., Venugopal, N., \& Reddy, S. L. N. (1995). Effect of endosulphan 35 EC on some biochemical changes in the tissues and haemolymph of a fresh water field crab. Barytelphusa guerini. Bulletin of Environmental Contamination and Toxicology, 55, 116-121.

Sambasiva, R. K. R. S. (1999). Pesticide impact on fish metabolism, (pp. 129-149). New Delhi: Discovery Publishing House.

Sathya, P. K. (1983). Studies on the toxic impact of Lindane on tissue metabolic profiles in the freshwater fish, Tilapia mossambica (Peters) with emphasis on carbohydrate metabolism (Ph.D. thesis). Tirupati: S.V. University.

Schneider, W. C. (1957). Determination of nucleic acids in tissue by pentose analysis. In S. P. Calowick, \& N. O. Kaplon (Eds.), Enzymology, (p. 680). New York: Academic Press.

Schumm, D. E., \& Webb, T. E. (1982). Site of action of colchicine on RNA release from liver nuclei. Biochemical and Biophysical Research Communications, 105(1), 375-382.

Sharaf El-Din, A. T., \& El-Sayed, K. A. (2001). Alteration in glucose, glycongen and lipid content in Biomphalaria alexandrina snails post-exposure to Schistosoma monsoni and Echinostoma liei miracidia. Journal-Egyptian German Society of Zoology, 36(D), 103-113.

Sharaf El-Din, A. T., El-Sayed, K. A., \& Mahmoud, M. B. (2004). Effect of Dithiopyridine carboxylic acid (herbicide) on Biomphalaria alexandrina snails and the free larval stages of Schistosoma mansoni. Journal-Egyptian German Society of Zoology, 43(D), 215-229.

Shiff, C. J. (1961). Trials with a new molluscicide Bayer 73 in southern Rhodesia. Bulletin of the World Health Organization, 25, 533-542.

Singh, A., Singh, D. K., Misra, T. N., \& Agarwal, R. A. (1996). Molluscicides of plant origin. Biological Agriculture and Horticulture, 13(3), 205-252.

Singh, D. K., \& Agarwal, R. A. (1991). Action sites of cypermethrin asynthetic pyrethroid in the snail Lymnaea acuminate. Acta Hydrochimica et Hydrobiologica, 19, 425-430.

Singh, N. P., McCoy, M. T., Tice, R. R., \& Schneider, E. L. (1988). A simple technique for quantitation of low levels of DNA damage in individual cells. Experimental Cell Research, 75, 184-191.

Tantawy, A., Sharaf El-Din, A. T., \& Bakry, F. A. (2000). Laboratory evaluation of the mollusciciding activity of Solanum lubium (Sclanaceae) against Biomphalaria alexandrina snails. J. Inter Cong Biolog Sci, 1(2), 307-318.

Tantawy, A. A. (2002). Effect of two herbicides on some biological and biochemical parameters of Biomphalaria alexandrina. Journal of the Egyptian Society of Parasitology, 32, 837-847.

Thompson, S. N., Lee, R. W., Mejia-Scales, V., \& El-Din, M. S. (1993). Biochemical and morphological pathology of the foot of the Schistosoma vector Biomphalaria glabrata infected with Schistosoma mansoni. Parasitol, 107, 275.

Tielens, A. G. M. (1994). Energy generation in parasitic helminths. Parasitology Today, 10, 346.

Trinder, P. (1969). Determination of glucose in blood using glucose oxidase with an alternative oxygen acceptor. Annals of Clinical Biochemistry, 6, 24-27.

Uyeda, K., \& Racker, K. (1965). Regulatory mechanisms in carbohydrate metabolism. VIl.Hexokinase and phosphofructokinase. The Journal of Biological Chemistry, 240, 4682-4688.

Van der Vies, J. (1954). Twomethods for the determination of glycogen in liver. The Biochemical Journal, 57, 410-416.

Vasanthi, R., Baskaran, P., \& Palanichamy, S. (1990). Influence of carbofuran on growth and protein conversion efficiency in some fresh water fishes. Journal of Ecobiology, 2, 85-88.

Vincent, S., Ambrose, T., Cyrill, L., \& Selvanaygam, M. M. (1995). Biochemical responses of the Indian major carp, Catla catla (Ham.) to chromium toxicity. Indian Journal of Environmental Health, 37, 192-196.

WHO (1965). Molluscicide screening and evaluation. Bulletin of the World Health Organization, 33, 567-581.

World Health Organization (2006). Report of the WHO informal meeting onUse of Triclabendazole in fascioliasis control. Geneva: WHO.

Youssef, A. A. (2010). Studies on the impact of some pesticides and Egyptian plants on some biological and physiological parameters of Biomphalaria alexandrina snails and their susceptibility to infection with Schistosoma mansoni miracidia. Egypt: M.Sc. Thesis, Faculty of Science, Al-Azhar University.

Zammit, V. A., Beis, L., \& Newsholme, E. A. (1978). Maximum activities and effects of fructose bisphosphate on pyruvate kinase from muscles of vertebrates and invertebrates in relation to the control of glycolysis. The Biochemical Journal, 174, 989 . 